\title{
Assessing the Enablers in the Implementation of Public Procurement Laws in Kenya. A Case of Meru County, Kenya
}

\section{Charles Mawira Kiremu}

To Link this Article: http://dx.doi.org/10.6007/IJARBSS/v10-i12/8151

DOI:10.6007/IJARBSS/v10-i12/8151

Received: 11 October 2020, Revised: 12 November 2020, Accepted: 27 November 2020

Published Online: 25 December 2020

In-Text Citation: (Kiremu, 2020)

To Cite this Article: Kiremu, C. M. (2020). Assessing the Enablers in the Implementation of Public Procurement Laws in Kenya. A Case of Meru County, Kenya. International Journal of Academic Research in Business and Social Sciences, 10(12), 638-661.

Copyright: (c) 2020 The Author(s)

Published by Human Resource Management Academic Research Society (www.hrmars.com) This article is published under the Creative Commons Attribution (CC BY 4.0) license. Anyone may reproduce, distribute, translate and create derivative works of this article (for both commercial and non-commercial purposes), subject to full attribution to the original publication and authors. The full terms of this license may be seen at: http://creativecommons.org/licences/by/4.0/legalcode

Vol. 10, No. 12, 2020, Pg. 638 - 661

Full Terms \& Conditions of access and use can be found at http://hrmars.com/index.php/pages/detail/publication-ethics 


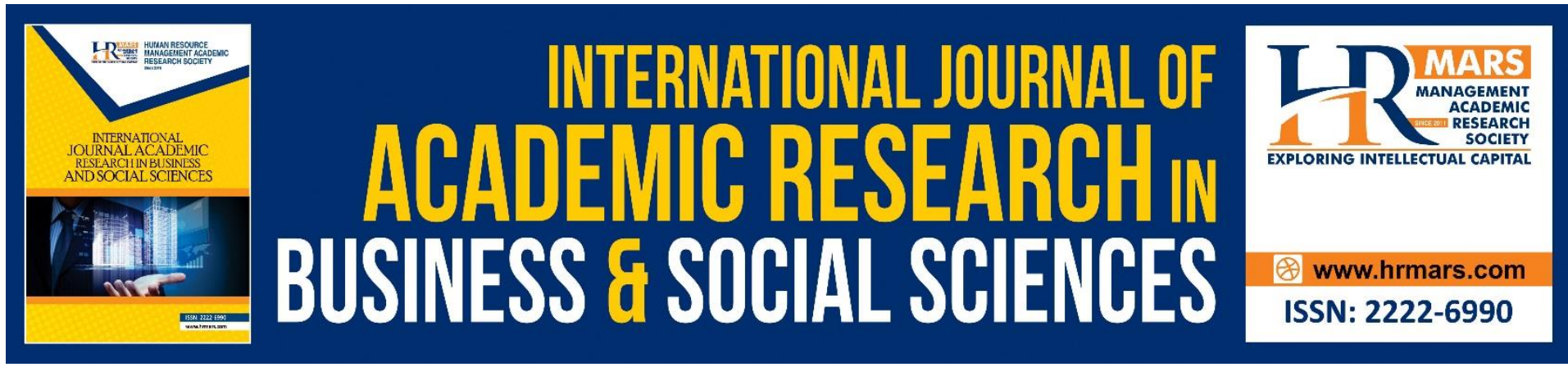

\title{
Assessing the Enablers in the Implementation of Public Procurement Laws in Kenya. A Case of Meru County, Kenya
}

\author{
Charles Mawira Kiremu \\ Master of Science Student in Procurement and Supply Chain Management \\ Mount Kenya University. \\ Email: kiremu03@yahoo.com
}

\begin{abstract}
Public procurement constitutes the biggest industry in the world. Governments worldwide using it to deliver services to the citizens. Owing to the importance of public procurement in service delivery and social-economic development, Public procurement laws are enacted to ensure that public procurement meets its desired outcomes. However implementation of these laws has been hampered with challenges hence failing to meet desired expectations. The study sought to find a relationship between the variables identified and targeted 324 public entities in Meru County. A sample of 96 , was selected with 12 used for the pilot testing and 84 the rest for the final study. A descriptive design was adopted for the study using a selfadministered structured questionnaire. Reliability of the instruments was tested through pilot testing. Data was summarized and presented using frequency charts and tables. The results of the study was that variables identified had proven that there existed a correlation between the variables and the implementation of public procurement laws. The findings of the study will inform policy guidelines design, practice and further research in public procurement.
\end{abstract}

Keywords: Assessment, The Enablers, Implementation, Public Procurement, Laws.

\section{Introduction}

Public procurement is the process of acquisition of any type of works, assets, services and goods by purchase, rental, lease, license, tenancy, franchise, or by any other contractual means using public funds from the private sector (World Bank, 2017). Governments procure goods, services and works on behalf of the citizens from their taxes and as such there is every need to ensure value for money (Van Weele, 2014:375). Public procurement ranges from routine day to day consumables to complex undertakings such as roads, ports and harbors, railway and management information systems (Monczka et al., 2008).

Globally public procurement contributes greatly in delivery of services and public entity performance (Dzuke\& Maude2015). Public procurement accounts for over $18 \%$ of the world's GDP. This easily translates to over $\$ 11$ trillion annually. Government or public procurement is one of the major single economic activities of any government which includes redistribution of incomes through provision of goods and services. In sub Saharan Africa, public procurement accounts for over $25 \%$ of the total GDP (La Harpe\& Le Roux, 2009:18) It follows 
therefore that public procurement is such an important activity that significantly impacts how taxpayers' money is spent and is a function that remains most vulnerable to corruption ( $\mathrm{TI}$, 2018). According to Mauro et al. (2015), the percentage of government expenditure through procurement as share of GDP among the leading economies was over $50 \%$ by 2011 . In the Netherlands, almost $45 \%$ of total government expenditure is through procurement (OECD, 2017). According to Bastagli, Coady \& Gupta (2012), many governments use Public Procurement to support the development of domestic industries, overcome regional economic imbalances, and support minority or disadvantaged communities.

Indeed, public procurement is the principal means through which governments meet developmental needs such as the provision of physical infrastructure and the supply of essential services (Ambe, Baden horst-Weiss, 2012). The public procurement system can immensely contribute to the economic development of these countries (PPOA, 2017). The journey to reforming the Public Procurement in Kenya has been long. Evolving from an archaic system without any formal legal backing, to a system of procurement that compares well with those of developed countries. Initially public procurement was conducted through treasury circulars and then to an orderly and legally regulated procurement system since March, 2001 under the Exchequer and Audit (Public Procurement) Regulations which created the Public Procurement Directorate (PPD) and the Public Procurement Complaints, Review and Appeals Board (PPCRAB).

Further efforts have been made as part of the overall Public Finance Reform and as a result of the implementation of these reforms, an act of parliament was enacted in 2005 , to formally regulate the conduct of procurement. This act came into force in the year 2007, following the formulation and gazettement of the public procurement and disposal regulations (PPOA, 2006). This act created various bodies to among other things monitor the implementation of the Act. These bodies include the Public Procurement Oversight Authority and the Public Procurement Administrative Review Board.

According to Mauro et al. (2015), the percentage of government expenditure through procurement as share of GDP among the leading economies was over $50 \%$ by 2011 . In the Netherlands, almost $45 \%$ of total government expenditure is through procurement (OECD, 2017). In Kenya the percentage of public procurement as a share of GDP is even higher since the government provides most of the services. Despite an increase in awareness and the presence of sound legal framework guiding procurement practices, the implementation of the public procurement laws in Kenya has been facing challenges. As a result of failure to implement these laws, massive procurement related frauds, corruption, misappropriation of funds and wastage of public resources continue to hinder the progress desired in service delivery, economic and social development. This study therefore sought to look at the enablers of the implementation of public procurement laws.

According to the Transparency International (2018), the latest Corruption Perception Index places Kenya at number 148 out of 180 countries with a mean score of just $28 \%$. This can be attributed to poor or lack of implementing the public procurement laws, which significantly impacts on the performance of the public entities in delivery of their mandate (Muriungi 2014).

According to OECD (2015), the highest percentage of financial fraud cases occur in the area of public procurement. That's why the Kenyan government has continuously carried out legal reforms and other frameworks to strengthen the institutions charged with the monitoring and implementing public procurement laws in order to check the wastage of resources. These reforms include the enactment of the Public Officer Ethics Act 2003, the Ant-Corruption and 
Economic Crime Act, 2004; the Public Financial Management Act 2012, and the Public Procurement and Disposal Act 2005 and its successor, the Public Procurement and Asset Disposal Act 2015. The aim was to make public procurement process more transparent and to ensure accountability.

The Act has created the Public Procurement Regulatory Authority as a strong regulatory and oversight institution for monitoring and linking public procurement to national budget and records management.

\section{Objectives of the Study}

This study was guided by the following objectives:

- To establish the extent to which professionally qualified and skilled staff influence implementation of Public Procurement laws in Meru County.

- To establish the extent to which management support influences the implementation of Public Procurement laws in Meru County.

- To establish the extent to which timely and adequate disbursement of funds influences the implementation of Public Procurement laws in Meru County.

- To examine the extent to which capacity to monitor compliance influence the implementation of the Public Procurement laws in Meru County.

\section{Research Questions}

The study sought to answer the following questions:-

- To what extent does staffing the procurement units with qualified and skilled staff influence implementation of Public Procurement laws in Meru County?

- To what extent does management support influence the implementation of the Public Procurement laws in Meru County?

- To what extent does adequate and timely disbursement of funds influence implementation of the Public Procurement laws in Meru County?

- To what extent does the capacity to monitor compliance influence implementation of public procurement laws in Meru of County?

\section{Literature Review Theoretical Review}

Contingency theory is a class of behavioral theory that claims that there is no best way to organize a corporation, to lead a company, or to make decisions. Instead, the optimal course of action is contingent (dependent) upon the internal and external situation. Several contingency approaches were developed concurrently in the late 1960s. Historically, contingency theory has sought to formulate broad generalizations about the formal structures that are typically associated with or best fit the use of different technologies. The perspective originated with the work of Joan Woodward (1958), who argued that technologies directly determine differences in such organizational attributes as span of control, centralization of authority, and the formalization of rules and procedures.

Mohsini and Davidson (1986) made use of contingency theory to examine the effects of structure and environment on performance, measured using the concept of conflict. Ireland (1983:25) indicates that he has used contingency theory to identify managerial actions affecting project performance. Kelly and Fleming (1986) have attempted to take this further and build models of the procurement system. This theory was found to be relevant to the study since the study looked into the aspects of qualifications, professional independence, 
capacity building and competence among staff, compliance, and facilitation and how it influences effectiveness of public procurement in a formal structure.

\section{The Agency Theory}

This theory was initially exposited by Alchian and Demsetz (1972) and later advanced by Jensen and Meckling (1976) and further modified by Sarens and Abdulmohamed (2019). The agency relationship is "one of the oldest and commonest codified modes of social interaction" Ross (1973). At the foundation of the agency theory is the assumption that there is an asymmetry of information between the two parties to a relationship in a given decisionmaking situation when one of the parties, referred to as the agent, acts on behalf of or represents the other party, referred to as the principal. According to Rungtusanatham et al., (2007) two parties create an agency relationship when they cooperate and engage in an association in which one party delegate decision making to another to act on its behalf. The key assumptions underlying this theory was the conflicting goals with each party acting in own self interests. The agents are more risk averse compared to the principal. The analysis of the agency theory helps identify the relativity and mutability of the subject matter of the cognition. The entity participating in the principal-agent relationship can be an individual person, entire groups of people, the state administration or an enterprise. Each party may have different (more precise, fuller) information on the subject of the relationship.

The agency theory has opened up new research perspectives, illustrating the relativity and mutability of the subject matter of the cognition. The subjects of the cognition are the relationships that typically assume the form of formalized contracts in various areas of the economy, such as on the insurance market, in the process of corporate governance, in the human resources management process in the organization, in the process of creating strategic alliances, in public-private partnerships, as well as in contracting for public services and tasks. The agency relationship appears whenever one of the parties must rely on the acts of the other. The agency relationship is a contract, under which the principal engages another person (the agent) to perform specific projects on its behalf, delegating decision making rights Jensen (1976). Three further assumptions are made in the agency theory:(a) the efficiency of the principal's operations depends on the agent's acts and decisions; (b) decisions are made by the parties to the relationship under conditions of uncertainty and risk, Eisenhardt (1989); (c) the principal and the agent have conflicting objectives to some extent, Daly (2015).Public procurement is not only a legal, but also an economic instrument. The decisions made by the awarding entity determine the conduct of the contractors and the effects of fulfilling the contract as early as at the start of the process of awarding the public contract. Ross (1973) explain that employees working in the public procurement must play an agent role for their entities. The theory fits this study as it established the relationship between implementers of the laws and effectiveness of the laws in meeting the desired objectives.

\section{Empirical Review}

The Impact of Skilled and Qualified Staff in the Implementation of Public Procurement Laws Employee academic qualification refers to the basic level of expertise required for a person to perform a certain specialized job. Academic qualification involves a combination of original preparation supported by subsequent activities that maintain or establish preparation for current job or professional responsibilities. During recruitment, academic qualifications are one of the requirements listed for a particular job. Employers predetermine employee future job performance based on their academic qualification on the assumption that employees 
with certain levels of academic qualification will perform better to a certain degree. The academic transcripts are assumed to reflect the candidate's strength and are expected to perform better in a working environment. Professional jobs should look at academic background and achievement as necessary conditions (Gordon \& Miller, 2012).The concept of academic qualifications of employees occupies an important place in the list of major concerns of the human resource management in all organizations around the world (Barbra 2006). This is partly because academic qualifications help in retaining the employees and on the other side it raises employee job performance level. There is a major difference between the academic qualifications and professional qualification in that the former lays great emphasis on the subject matter through coursework and research while professional qualification is mostly achieved through practice. But both are important for the efficiency in the procurement practice. The purpose of a profession is to impart knowledge, understanding and practical experience to the learner to apply the knowledge in a practical manner in a professional practice. In South Africa for instance, despite the reform process in public procurement, problems have been identified in non-compliance with legislation, insufficient training, lack of experience and inadequate qualifications (Ambe\&Badenhorst-Weiss (2012). Lack of adequate training also leads to challenges of using the right procurement methods as recognized by Ameyaw et al. (2012), and the use and preparation of right documents.

In recognition of the effect procurement has on the total government spend, the government of Kenya through the national assembly, enacted the Public Procurement and Asset Disposal Act 2015. This Act establishes various bodies charged with the responsibility of ensuring compliance with the act. Section 47(1) stipulates that the procurement unit shall be handled by procurement professionals whose qualifications are recognized in Kenya. The Supplies Practitioners Management Act 2007 defines the qualifications required for one to be qualified as a procurement profession. It also established the Kenya Institute of Supplies Examination Board which has the power to determine the course of study and the nature of examinations required to be passed for one to be recognized as a professional. The public procurement and Asset Disposal Act 2015 lays a lot of emphasis on having the right persons manning the procurement units. These persons must possess the right academic qualifications as specified by an act. One of the key responsibilities of the Accounting Officer in the Procurement entities is to ensure that the procurement units are staffed to an appropriate level with procurement professionals. These are people who have gone through the requisite academic programme in procurement matters. Besides the Act now makes it mandatory for the head of the procurement unit to prepare an independent professional opinion to be presented to the head of the entity or the accounting officer before the award is made and the head or accounting officer must put into consideration the professional opinion.

Research on qualification as a contributor to implementation of procurement laws has been carried out in various countries around the world but not conclusively. Mugo (2013) conducted a study on the effect of staff qualification and skills, technology and governance policies in determining procurement regulatory compliance focusing on KenGen. Among others the study found out that an organizational structure is a determinant of compliance with regulations and made a recommendation that qualified and skilled professionals with skills and knowledge on procurement needs to be engaged. However the study having focused on a single entity may not have been applicable to a wider cross-section of public procurement entities due to their nature. This study therefore sought to focus on a wider spectrum of entities in Meru County. 


\section{Management Support and Its Impact in the Implementation of Public Procurement Laws}

According to the Journal of Transport and Supply Chain Management (2015), public procurement has not been given the recognition it deserves. This is so especially in the developing countries where public procurement function is regarded as a support unit to a bigger department like finance or administration. It therefore means that the unit cannot attract the requisite facilitation to enable it cope with the ever changing business environment. Most entities have the procurement units manned by un-professional staff due to the casual nature of how they view it (Mehra\&Inman, 2004). Not much management goodwill is put in place to advance the institutional support in improving the working environment (Hunja, 2003). However procurement in developed world has assumed strategic nature and forming part of the core business strategies. Companies and countries are seeing the procurement profession for what it is; a catalyst for profitability and effective service delivery. According to Gocke (2008), in the past procurement and especially public procurement was viewed as necessary but not fully appreciated. The key decisions on what to procure, when to procure and from who to procure was done elsewhere and the procurement function only required to implement the decisions. But with the changing environments brought about in part by the improvement in technology, firms and governments are waking up to the reality that if well managed procurement is the key link to profitability and efficient service delivery. The need to think strategically in view of the shrinking budgetary provisions has led to a whole new dimension in the way public procurement is approached (Anthon, Bogetoft \& Thorsen, 2007)

According to Hadfield (2011), for procurement functions to perform optimally, management support is critical. Their changing roles from support function to strategic nature incorporating monitoring supply markets, interpreting the effect of market trends and globalization in expansion of supply base, calls for effective facilitation from management. Management support reduces the instances where the turnover of employees is high (Chiboiwa, Samuel and Chipunza, 2010). Human resource remains the most important asset in any establishment. They expect to be rewarded or recognized according to the efforts they put in the organization (Laoledch, Land \& Low, 2008). According to expectancy theory by Vroom a person expects the efforts which he/she puts in to be rewarded (Van Eerde\&Thierry, 1996). Lack of equity and justice which is the manifestation of poor management involvement leads to apathy in execution of duties (Howard \&Miller, 1993)

Kiama (2014) carried out a study on factors affecting implementation of the PPDA2005 in the SACCO societies in Kenya with strategic planning, enforcement and organizational culture as the main variables. The study targeted procurement officers and general managers. The results of the findings were that impact of regulations was very high and the organizational culture influenced good procurement procedures. The study looked at variables similar to the ones proposed for this study as it factored in enforcement and organizational culture. This study compared the results to see how they compared with other public procurement entities other than SACCOs.

\section{The Effect of Adequate and Timely Disbursement of Funds in Implementation of Public Procurement Laws}

Effective procurement performance is pegged on the timely disbursement of funds. These funds should also be in sufficient quantities to meet the planned expenses. Inadequate and late releases of funds have been blamed for the slow and often costly completion of major and complex projects. This realization has made major donors to adopt new approaches 
towards improving their mode of disbursements for funding major projects in developing countries (Kanbur, 2000). Nkamelu in a study conducted in Botswana, between the years 1990 to 2007 , it was established that at the inception of a project there was considerable delay between the date of funds commitment and the first disbursement. The trend had adverse effect on the preliminary activities. Soumare and Gouhou (2009) pointed out that a delay in disbursement of funds impacts negatively on the performance of the projects and is the difference between success and failure. The Public Procurement and Asset Disposal Act 2015 require that at the beginning of every financial year, the heads of public entities must prepare a realistic procurement and asset disposal plan. This forms part of the budgetary process. The main purpose of procurement planning is to help the public entities know in advance the choice of procurement method to use when the actual procurement commences. The PFM Act 2012, article 45, provides that at the end of every financial year if an appropriation has not been spent, it immediately lapses. It further provides that the unspent appropriation shall be repaid or returned to the National Exchequer Account by the public entity and a statement of the same made to the Controller of Budget.

For many years now, most public entities have been complaining that the National Treasury releases funds too close to the financial year making it difficult to properly utilize the funds and occasioning the return of the same to the Exchequer. The Council of Governors has consistently complained that the irregular disbursement of funds has negatively affected their capacity to utilize their budgeted provisions (COG, 2017). In order to beat the June $30^{\text {th }}$ deadline and avoid returning the appropriated funds, most public procurement entities engages in impulse procurement which does not allow them time to follow the due process. This has created room for corrupt practices and wastage as sometimes what was bought may not necessarily be appropriate but rather to ensure that none of the funds is returned. This has seen various entities implore the national assembly to make amendments to ring-fence some of the appropriated funds like development fund from the requirement to return unutilized funds. Already the Constituency Development Fund has been ring-fenced from the requirement.

\section{The Impact of Compliance and Monitoring Capacity in the Implementation of Public Procurement Laws}

The monitoring refers to the observance and careful checking of progress or quality of a defined objective over some defined period of time and with warning for deviation (Oxford Dictionary of English). It is the intermittent series of observations in time, carried out to show the extent of compliance with formulated standard or degree of deviation from an expected norm. Monitoring of public procurement comprises each and any systematic observation of the public procurement system conducted in a coherent way in order to assess how this system functions and develops over time and to establish whether the desired (targeted) state defined by policy makers are achieved (Hellawell, 1991)

The problem with compliance of the procurement laws has been witnessed in a cross section of countries. According to Gillott \& Wong (2016), Ontario's public services sector has been troubled by a number of highly publicized procurement scandals. This has forced the provincial government to implement measures including the broader public sector procurement directive to guide public procurement sector organization. Part of the reasons contributing to non-compliance has been the nature and size of the public entities who feel their budgets are too small. Other reasons include the requirement to segregate the five procurement roles i.e. requisition, budgeting, commitment, receipt and payment. Owing to 
their sizes, these small entities can't raise the required personnel to handle these separate roles.

Osei-tutu, Mensah and Ameyaw (2011) determined compliance levels with implementation of public procurement law in Ghana. Poor compliance with the laws was found to result from inadequate procurement professionals to handle public procurement, little resources to purchase goods in bulk or economical quantities, poor information access and procurement plans. Having focused on compliance alone, the study fails to bring out other factors that impair effectiveness of public procurement laws. This study looked at some other enablers apart from the compliance alone.

Geldermana et al., (2006) undertook studies on the non-compliance with the European Union tendering directives among some 147 procurements professionals within the Dutch defense ministry and found out that familiarity of the rules on the part of the buyer and the organization's incentives bring out a positive impact on compliance. Ones and Carey (2010), in a study conducted in the United Kingdom on user perceptions of e-procurement quality among 274 respondents revealed that system compliance was greatly influenced by professionalism and content dimension, with contract compliance being influenced by processing and specifications. Since the study was done in a developed country, its application in third world countries like Kenya may be untenable owing to technological differences. In Spain the public procurement observatory has recently been established with duties being to increase transparency, competitiveness and integrity of the Spanish public procurement system, increase efficiency of public procurement on both supply and demand, facilitate access of small and medium enterprises, boost innovations, promote the participation of Spanish enterprises in the international public procurement market(Sigma, 2013).

According to Sigma (2011) there are three types of monitoring: audit of compliance (procedural compliance), performance evaluation/performance measurement and policy compliance. Ojo and Gbadebo (2014) studied the reasons for non-compliance with the procurement laws in Nigeria from a sample of 100 respondents and identified familiarity of rules and political interference in decision making were the main impediments to compliance. Gesuka and Namusonge (2013), conducted a study on the factors affecting compliance in the Public Procurement in the Kenyan context using a sample of 70 respondents in Butere District and some level of compliance with the legal requirements but also revealed weak familiarity of procurement rules among the key stakeholders. This study sought to further the body of knowledge in expanding the scope through studying other variables that could be the cause of ineffectiveness

\section{Conceptual Framework}

The figure below shows independent and dependent variables of the study and how they related to each other. The main objective of the study was to analyze the enablers of the effective implementation of the Public Procurement laws in Meru County. The independent variables identified were; skilled and qualified staff, management support, and timely and adequate disbursement of funds and monitoring of compliance with the laws. By being skilled and qualified means that one has adequate knowledge about the subject matter and can take or follow instructions form an informed point of view. It means one has gone through the requisite academic training and where the academic training is not in line with the subject matter, one has undergone trainings to improve skills in the subject matter.

Management support entails creating an enabling environment for procurement units to perform optimally. This includes providing facilities, equipment and other resources. 
Procurement being a process means that without proper facilitation, the implementation of the laws may not be possible as some processes will either be delayed or omitted owing to lack of facilities. The department will in no doubt require to make independent decisions and be in full control of their activities. The need to ensure adequate authority and responsibility within the law. Without a doubt, adequate funding ensures that procurement plans are implemented and budgeted appropriations used for the intended causes. Compliance monitoring ensures that those charged with procurement responsibilities abide by the policies set and any deviation can be corrected in good time. It also provides an opportunity for accessing need for capacity building where it is lacking.

Independent Variables

\section{Skilled staff with procurement qualification}

-Level of academic qualification

- Capacity building and Training

- Needs assessment

\section{Management support}

- Provision of a conducive environment

- Facilities

\section{Adequate and timely disbursement of funds}

- Frequency of disbursement

- Procurement planning

\section{Compliance and monitoring capacity}

- Number of visits

- Internal monitoring team

- Internal policy document

\section{Dependent Variable}

\begin{tabular}{|l|l|}
\hline & $\begin{array}{l}\text { Implementation of } \\
\text { public procurement } \\
\text { laws. } \\
\text { - Compliance with } \\
\text { budgetary provisions } \\
\text { - Value for money on } \\
\text { goods and services } \\
\text { procured } \\
\text { - Effective service } \\
\text { delivery } \\
\text { - Professional service } \\
\text { delivery } \\
\text { - Minimal supplier } \\
\text { complaints } \\
\text { - Integrity }\end{array}$ \\
\hline
\end{tabular}

Figure 1: Conceptual Frame work

Source: Researcher (2018)

Though there are previous studies on the implementation of public procurement laws in Kenya, no single study has been done in relation to compliance as an enabler in the implementations of public procurement laws. This study therefore identified the following knowledge gaps in the area of compliance as effect of monitoring for compliance by the Public Procurement Regulator, internal compliance mechanism and effects of lack of monitoring. 


\section{Research Methodology}

The study employed qualitative and quantitative research methodology. Primary data was collected from the respondents through use of questionnaires in an attempt to evaluate the link between the identified independent variables to the dependent variable. The questionnaires were chosen for the study as they are a reliable and quick method of collecting data from multiple respondents in an efficient and timely manner. The secondary data was collected form the various published reports from the Auditor General, Public Account Committees of the National Assembly and the various regulatory Bodies.

For this study, descriptive research design was used. Descriptive research design is a scientific method of research which attempts to determine, describe or identify the relationship between variables (Vogt, Diana Lynne 2013). It answers the questions of who, where, when, what and how associated with a particular research problem. The researcher found it to be the best design for this project as it sought to assess how the identified independent variables contributed to the dependent variable. The variables identified were; skilled staff with procurement qualification, Management support for procurement units, adequate and timely disbursement of appropriated or budgeted funds and compliance and monitoring capacity, and how they influence the implementation of procurement laws. It was aimed at casting light on current issues or problems through a process of data collection that enabled description of the situation more completely (Gorard, 2013; Darwish et al., 2020) The study targeted three hundred and twenty-four heads of various categories of public procurement entities in Meru County, Kenya.

Table 1 Sampling Frame

\begin{tabular}{lccr}
\hline Category of Procuring Entity & Target population & Sample size & Percentage (\%) \\
\hline Public secondary schools & 258 & 50 & 52 \\
Public technical institutes & 7 & 7 & 7 \\
Public universities & 1 & 1 & 1 \\
National Government entities & 32 & 24 & 25 \\
County Government entities & 18 & 12 & 13 \\
Parastatals and other Agencies & 8 & 2 & 2 \\
\hline Totals & 324 & 96 & 100 \\
\hline
\end{tabular}

Source; Researcher (2018)

\section{Data Analysis}

Data analysis involved reducing accumulated data to a manageable size, developing summaries looking for patterns and applying statistical techniques (Kombo and Tromp, 2011). After the questionnaires were collected from the field, they were adequately checked for reliability and verification before being analyzed. The qualitative data generated from the study were categorized in different themes according to research questions and reported in a narrative form together with the quantitative data while the quantitative data was analyzed through the use of frequency distribution tables and percentages in order to answer the specific objective. 


\section{Research Findings}

The researcher used questionnaire as an instrument to gather data for the study. Towards this delivery was made for a total of 84 questionnaires to the respondents out of which were 78 were filled and retuned. 6 questionnaires were never returned. This gave a response rate of the questionnaires at $92.86 \%$. The high response was achieved as in most of the cases; the researcher self-delivered the questionnaires to the respondents and collected them immediately they were filled. The questionnaire was divided into two parts A and B. Part A sought general information from the respondents like their levels of education, gender, and age and employment status while part B sought information key to the study. The responses to all the questions asked were as follows;

Table 2: Demographics of the Respondents

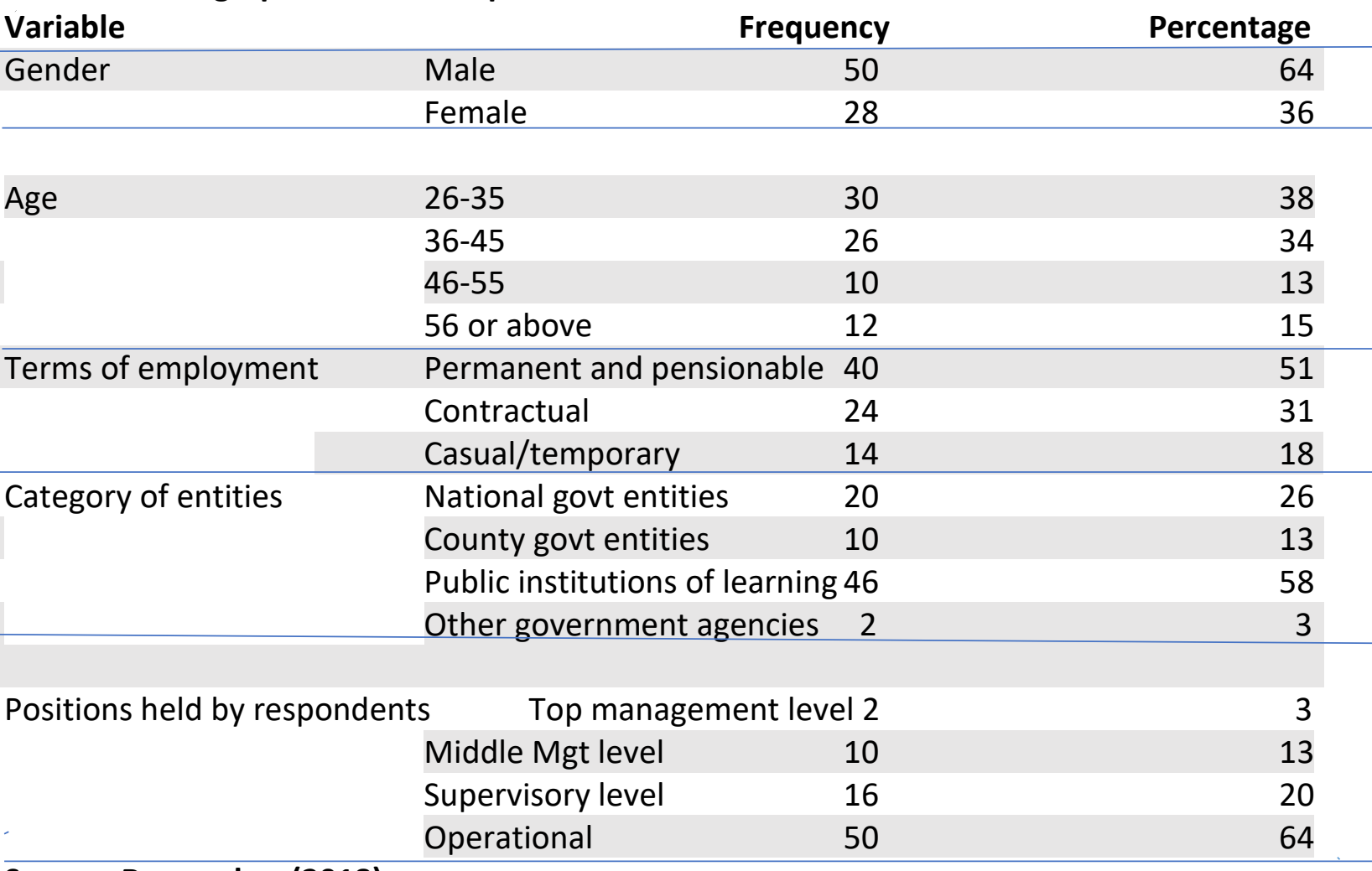

Source; Researcher (2018)

Table 3: Levels of Education, Understanding of the PPADA and Training

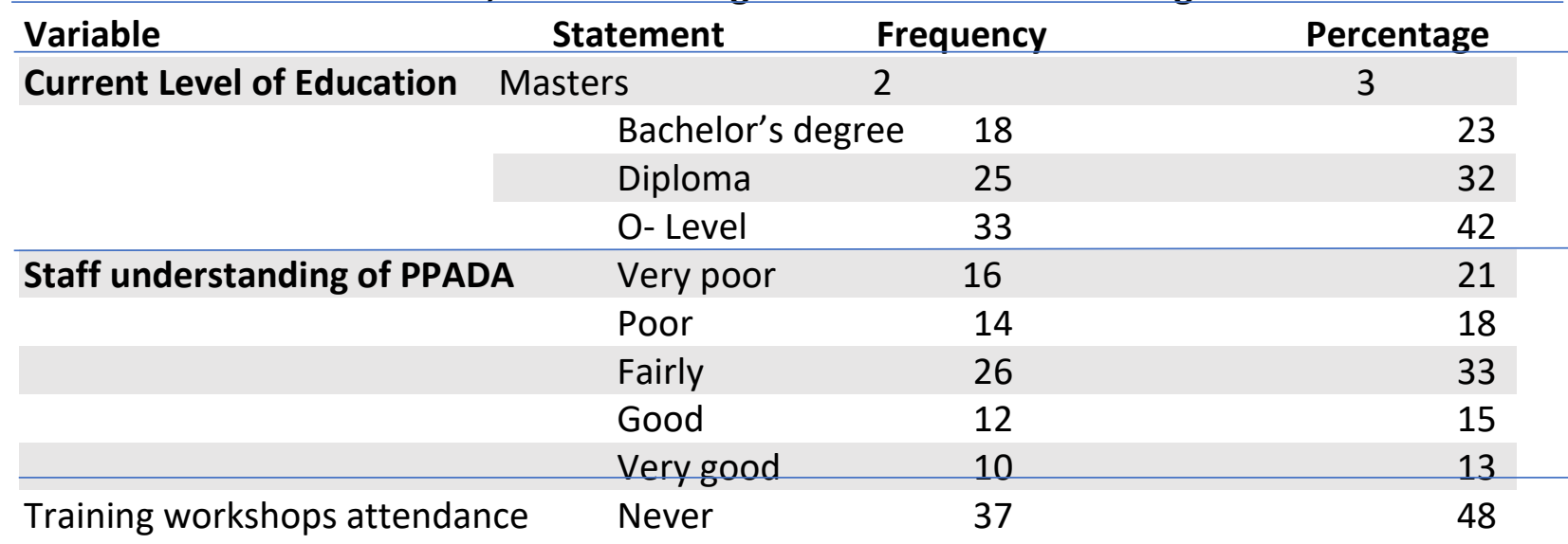




\begin{tabular}{llcr} 
& 1-2 times & 33 & 42 \\
& 3-4 times & 8 & 10 \\
& $5-6$ times & 0 & 0 \\
& Over 6 times & 0 & 0 \\
\hline Training needs assessment & Never & 40 & 51 \\
& $1-2$ times & 31 & 40 \\
& 3-4 times & 7 & 9 \\
& 5-6 times & 0 & 0 \\
& Over 6 times & 0 & 0 \\
\hline
\end{tabular}

Source; Researcher (2018)

Table 4: Level of Professional Independence, Decision Making and Authority

\begin{tabular}{|c|c|c|c|}
\hline Variable & Response & Frequency & Percentage \\
\hline \multirow[t]{5}{*}{ Level of Professional Independence } & Very poor & 29 & 37 \\
\hline & Poor & 16 & 20 \\
\hline & Fair & 10 & 13 \\
\hline & Good & 15 & 19 \\
\hline & Very good & 9 & 11 \\
\hline \multirow[t]{5}{*}{ Level of Decision Making } & Very poor & 28 & 35 \\
\hline & Poor & 20 & 26 \\
\hline & Fair & 10 & 13 \\
\hline & Good & 10 & 13 \\
\hline & Very good & 10 & 13 \\
\hline \multirow[t]{5}{*}{ Level of Departments Facilitation } & Very poor & 22 & 28 \\
\hline & Poor & 20 & 26 \\
\hline & Fair & 10 & 13 \\
\hline & Good & 18 & 23 \\
\hline & Very good & 8 & 10 \\
\hline \multirow[t]{5}{*}{ Level of Political Goodwill } & Very poor & 26 & 33 \\
\hline & Poor & 21 & 27 \\
\hline & Fair & 14 & 18 \\
\hline & Good & 9 & 12 \\
\hline & Very good & 8 & 10 \\
\hline \multirow[t]{5}{*}{ Level of Level of Authority } & Very poor & 20 & 26 \\
\hline & Poor & 20 & 26 \\
\hline & Fair & 15 & 19 \\
\hline & Good & 13 & 16 \\
\hline & Very good & 10 & 13 \\
\hline
\end{tabular}

Source; Researcher (2018)

Table 5: Procurement Planning and Effect, Rate and Frequency of Disbursement of Funds

\begin{tabular}{llcc} 
Variable & Response & Frequency & \\
Percentage & & 54 & 69 \\
\hline Undertaking procurement planning & Yes & 24 & 31 \\
\cline { 2 - 4 } & No & 54 & 69 \\
\hline Does it affect procurement performance Yes & 24 & 31 \\
\hline No & 54 & 69
\end{tabular}




\begin{tabular}{llrr} 
& No & 24 & 31 \\
\hline How do you rate the frequency & Very poor & 24 & 31 \\
& Poor & 30 & 38 \\
& Fair & 16 & 21 \\
& Good & 8 & 10 \\
& Very good & 0 & 0 \\
\hline
\end{tabular}

Source; Researcher (2018)

Table 6: Compliance Monitoring, internal mechanisms and effect of lack of monitoring on implementation of public procurement laws.

\begin{tabular}{llcc} 
Variable & Response & Frequency & Percentage \\
\hline Has your unit been monitored by PPRA & Yes & 54 & 69 \\
& No & 24 & 31 \\
\hline
\end{tabular}

Do you have an internal compliance mechanism?

\begin{tabular}{lll} 
Yes & 48 & 62 \\
\hline & 30 & 38
\end{tabular}

Does lack of monitoring affect compliance of procurement laws in your entity?

\begin{tabular}{|c|c|c|}
\hline Yes & 60 & 77 \\
\hline No & 18 & 20 \\
\hline
\end{tabular}

Source; Researcher (2018)

\section{Discussion of Individual Objective Results}

$>$ The Impact of Skilled and Qualified Staff in the Implementation of Public Procurement Laws.

In order to establish the extent to which professionally and skilled staff influenced the implementation of public procurement laws in Meru County a number of questions were asked of the respondents. The questions sought the respondent's opinion based on a scale starting from the lowest to the highest. From the responses given, on the levels of education a vast majority of those working in the procurement units do not possess sufficient academic qualifications. $42 \%$ of the staff were reported to possess ordinary level of education. The numbers decline as one moves up the academic ladder with only 3 percent of the staff possessing post graduate studies in procurement. Laws are drafted in technical terms which requires the implementers to understand them. There is therefore proof that lack of adequate academic training on the relevant subject is an impediment to the implementation of the public procurement laws. On the issue of the staff understanding of the procurement laws a vast majority at $39 \%$ have very poor and poor ratings in the understanding of the relevant law governing public procurement. Only $13 \%$ have a very good understanding of the law.

The study found that $48 \%$ of the staff have never attended any form of training to improve their skills in implementing public procurement laws. $42 \%$ have attended training only once or two times in a year. This coupled with the poor assessment of training needs, with $51 \%$ reporting that they never carry out assessments to determine the training needs of their staff in skills improvements, answers the research question on whether staffing the procurement department with qualified and skilled staff influence the implementation of the public procurement law in Meru County. The figures below graphically depict the levels of staff understanding of the relevant procurement law and the number of times the entities conduct training needs assessment. 
It therefore shows that a vast majority of the procurement staff in the studied public entities have little understanding of the laws governing Public Procurement. One would have expected that training opportunities would be made available to ensure that the staff skills are improved but as the graph below shows majority of the entities do not conduct training needs assessment to determine the levels of training needed to make the staff knowledgeable in matters procurement.

The figure below shows the results of the study as obtained from the respondents on the frequency of staff training needs assessment annually.

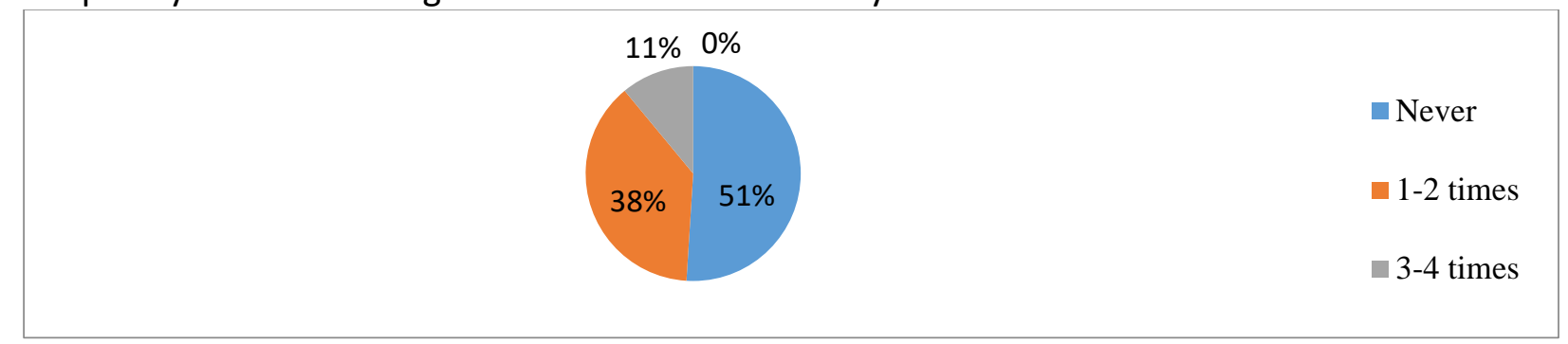

Figure 1; Frequency of Training Needs Assessment in a Year Source; Researcher (2018)

More than half of the entities never conduct training needs assessment. 38\% said that they did it at least once in a year with a further $11 \%$ saying they conducted training needs assessment at least three times in year.

$>$ To Establish the Extent to Which Management Support Influences the Implementation of Public Procurement Laws.

This question sought to gauge how the heads of the procuring entities thought of the independence of the procurement decisions they made in their departments. The view of the researcher was that management support was necessary for any department to function properly. Towards this view, the study asked a number of questions meant to support or negate the view. From the responses received it was clear that management support toward the procurement departments was lacking especially in the areas of professional independence of the department, decision making regarding procurement matters, political goodwill towards encouraging the departments to fully implement the public procurement laws, departmental facilitation and the levels of authority and responsibility. The graphs below visually capture the picture of the low levels of management support across several critical areas relevant for optimal functioning of the procurement units.

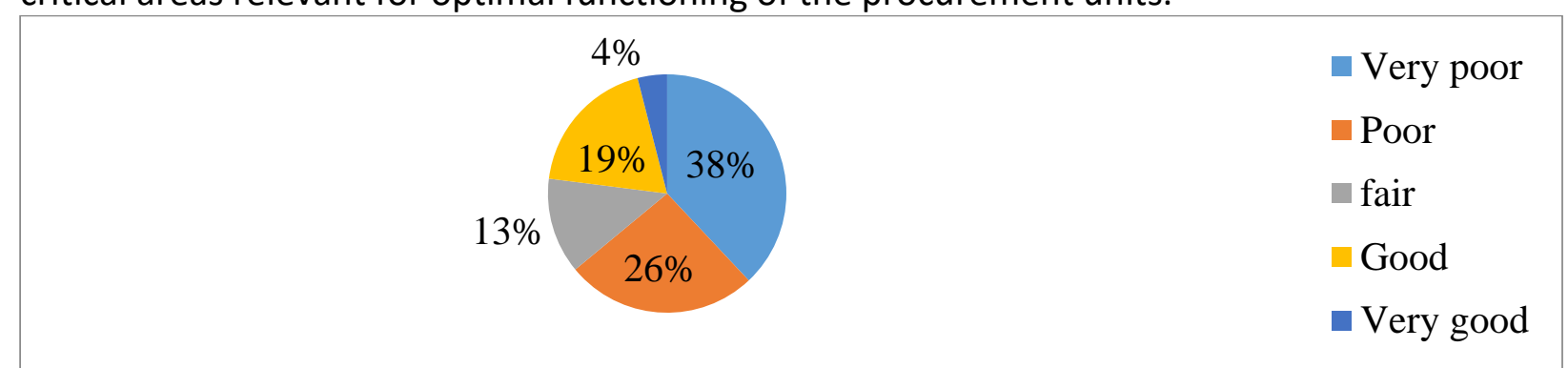

Figure 2; Rating of Level of Professional Independence.

Source; Researcher (2018) 
From the study, $38 \%$ of the respondents felt that the level of independence was very poor while $26 \%$ felt the levels were poor. $13 \%$ felt their level of independence were fair while $19 \%$ and $4 \%$ felt their levels were good and very good respectively. The lack of independence is bound to affect the levels of compliance with the laws since the procurement departments are not in control of their own activities and simply implement decisions of other actors.

On the levels of decision making as per figure 3 below, results of the study on the question were that $38 \%$ of the respondents felt that their decision making levels were very poor and $28 \%$ feeling they were poor. $13 \%$ felt their decision making levels were fair while $13 \%$ and $8 \%$ felt they were good and very good respectively. The majority of those who rated their decision making as being very good are mostly those from the higher education institutions. The worst performers here are the national and county governments' entities.

$\begin{array}{ll} & \text { Very poor } \\ & \text { Poor } \\ & \text { Fair } \\ & \text { Good } \\ & \text { E Very good }\end{array}$

Figure 3; Level of Decision Making in Procurement Department Source; Researcher (2018)

The figure below presents graphically the results on the question of departmental levels of facilitation.

\begin{tabular}{|l|l|} 
& Very poor \\
Poor \\
जair \\
a
\end{tabular}

\section{Figure 4; Level of Departmental Facilitation to Perform Optimally Source; Researcher (2018)}

From the respondents, $28 \%$ felt that they were very poorly facilitated and $26 \%$ felt they were poorly facilitated. $13 \%$ felt the level of facilitation was fair while $26 \%$ and $7 \%$ felt the level of facilitation was good and very good respectively. Although slightly more than half of the entities have not adequately facilitated their procurement departments, there is remarkable effort as at least some combined $46 \%$ report some levels of facilitation with $33 \%$ being considered satisfactory. This can be attributed to there being different categories of public procuring entities each with varying management styles and approaches to their procurement departments 


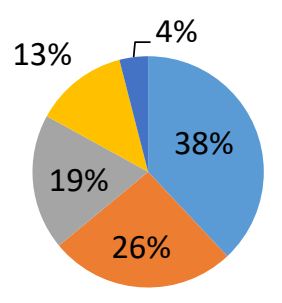

Very poor

- Poor

Fair

Good

- Very Good

\section{Figure 5; Level of Political Goodwill} Source; Researcher (2018)

Figure 5 above on seeking to understand how well the political leadership supported the procurement unit's independence in making procurement decisions especially in the county assembly and the National Government Constituency Development Funds, 38\% felt the level of political goodwill was very poor and $26 \%$ was poor. $19 \%$ felt the level was fair with $13 \%$ and $4 \%$ believing the level of goodwill was good and very good respectively. Without the political or leadership goodwill it would be difficult to implement the procurement laws as the tendency is to bend towards the whims of those wielding political power. This is more prevalent with development projects with strong political inclinations.

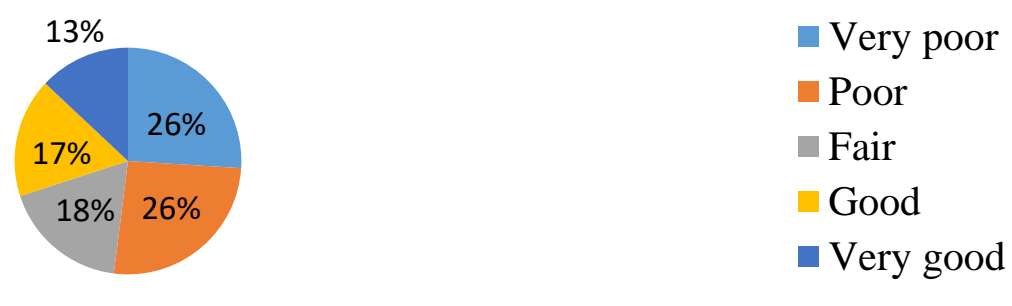

Figure 6; Level of Authority Granted to Procurement Department Source; Researcher (2018)

On the question of how the procurement units felt that the management granted them the necessary authority to perform their duties in an atmosphere where the actions of the department are fully controlled by the departments themselves, $26 \%$ felt that the levels were very poor. $26 \%$ felt the levels were poor. A further $18 \%$ felt the levels were fair and $17 \%$ and $13 \%$ felt their levels were good and very good respectively.

To Establish the Extent to Which Timely and Adequate Disbursement of Funds Influence the Implementation of Public Procurement laws.

Procurement function is all about spending. The importance of the department is through various steps and research to help procuring entities get value for money on the monies spent. One way of ensuring value for money is through implementation of public procurement laws which regulate how, when and what should constitute an economical expense of the public resources. Timely and adequate disbursement of the funds budgeted for various heads therefore would go a long way in ensuring this prudent spending. One of the best avenues of ensuring prudent usage of funds is through conducting procurement planning. By planning one knows in advance what is required, when required and the best method to acquire it, and from what source. The study therefore sought to know if the procuring entities in Meru county conduct procurement planning and a very satisfactory 
number at $69 \%$ did agree to conduct the procurement planning. A very large number of respondents at $72 \%$ also admitted to procurement planning positively affecting their procurement performance.

However this impressive number of entities conducting the procurement planning is overshadowed by the poor rate on the disbursement of funds which affected their entities planning at $74 \%$. It was also found out that the frequency of the disbursement was very poor at $45 \%$ with only $10 \%$ describing the frequency of disbursement as being good. This therefore means that the rate and frequency with which the funds are released are not satisfactory and have a corresponding effect of impeding the implementation of the public procurement laws. The council of governors are on record as complaining that a large of funds appropriated for their development projects ends up being surrendered to the treasury for lack of utilization basically due to the funds being disbursed very close to the end of fiscal year. This causes the counties to carry huge unpaid bills by the beginning of new fiscal year. This problem also affects many other public departments who are so often accused of poor absorption rate as funds are returned unspent to the treasury. In an effort to make use of the funds within the shortest time period between receipt and close of the fiscal year, many entities have tended to engage in all manner of tricks which has encouraged wanton misuse of public resources like the case of the National Youth Service where suppliers were paid full amounts without supplying anything of equivalent value.

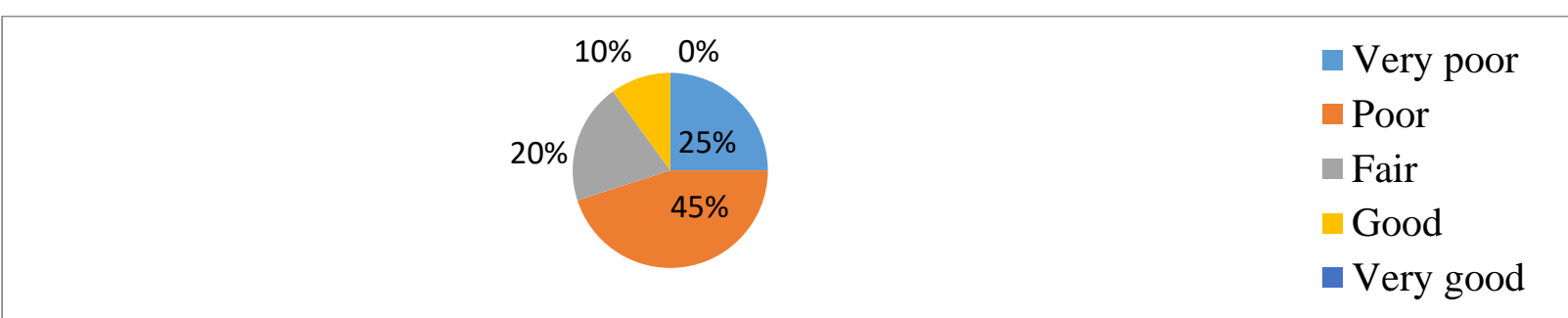

\section{Figure 7; Rate of Frequency of Funds Disbursement Source; Researcher (2018)}

No respondent thought the frequency was very good. Other than the higher institutions of learning, every other category felt that the rate at which appropriated fund were disbursed affected their planning. This could be as a result of these institutions receiving most of their revenue from fees and tuition payments. It's worth noting that the majority of those who faulted the frequency of disbursement were those working in the county and national government entities.

\section{$>$ To Examine the Extent of Compliance Monitoring in the Implementation of Public Procurement Laws.}

The Public Procurement and Asset Disposal Act of 2015 which the current law governing public procurement in Kenya in creates in part 2, section 8 , a body known as the Public Procurement Regulatory Authority which is a body corporate and whose mandate among others is to; monitor the public procurement system and report on the overall functioning of it and present to the cabinet secretary and the county executive member for finance in each county such other reports and recommendations for improvements, provide advice and technical support upon request enforce standards developed under the act and inform as applicable the cabinet secretary parliament the relevant county executive member of finance the relevant county assembly or auditor general on issues of noncompliance with 
procurement laws once the relevant state organ or public entity ignores the directive of the Authority including material breaches of the measures established under the act. In order to fulfil its mandate toward enhancing compliance the authority created a department whose duty is to monitor and build capacity of procurement entities to comply with the laws. In order to determine whether lack of monitoring for compliance affects the implementation of public procurement laws in Meru county the researcher sought through a set of questions to get information from the heads of procuring departments in the public procuring entities on whether their entities have been monitored for compliance by the relevant authority. It also sought the respondents' views on whether they have in place internal compliance mechanisms in form of policies and guidelines to ensure the processes conform to the laws and finally their views on whether monitoring or lack of monitoring affected compliance of public procurement laws in their entities in Meru County.

On the question having been monitored for compliance by the relevant regulatory body, $90 \%$ of the public entities in the county reported not to have been monitored. It was only $10 \%$ of the entities who reported to having been monitored since the coming to existence of the body. Although the issue of capacity may be the reason for the dismal performance in the monitoring the authority should put effort in ensuring that the entities are monitored and remedial steps put in place to ensure compliance.

Procurement units must also be encouraged to have internal compliance mechanism, through policy guidelines detailing the steps needed to be taken at every stage of the procurement process to ensure that there is compliance with the laws. This is as a result of $55 \%$ of the respondents having no internal compliance mechanism while only $45 \%$ had internal compliance monitoring mechanism.

On the opinion sought from the respondents on whether monitoring had an effect on the implementation of procurement laws, $80 \%$ of the respondents believed that lack of monitoring affects the compliance levels while 20\% didn't believe that it affects the compliance of the laws. Monitoring points out the areas of departure and helps in identifying the gaps which need to be filled including the need for training and retraining. The researcher can as such determine that monitoring for compliance has an effect on the implementation of public procurement laws in Meru County.

\section{Conclusions}

From the study it's clear that the identified variables have an impact in the implementation of the public procurement laws. There is need to have qualified professionals manning procurement units in the public entities. Lack of personnel who are skilled in procurement matters makes it difficult to translate the laws and put them into practice. Majority of the staff in procurement units do not hold the requisite qualifications. Only few of the respondents had the procurement qualifications beyond the O-level.

The study report shows that majority of the respondents do not have a good understanding of the procurement laws. The laws being technical in nature would require persons who are professionally qualified to interpret them and apply them. This would therefore necessitate training the staff to better understand the laws.

It is clear that for reasons which this study had not sought to find out owing to the nature of the instrument used, there doesn't exist elaborate training regimes for the staff to improve their skills in the procurement functions in majority of the respondents. This impedes their decision making and professional independence. A knowledgeable qualified staff would be in a position to stand their ground for what they believe to be the right thing. Unqualified and 
inexperienced staff would take directions which are not necessarily theirs or conforming to the dictates of the law.

Management support is equally important for the procurement units to perform their functions effectively. From the study it's clear that the units don't feel the support of the management. Overwhelming majority of the respondents believed that they didn't have the right facilitation for the proper functioning of their departments. Neither did their facilities meet the requirement for optimal performance. The levels of authority and responsibility granted to the procurement departments also were very low. Respondents felt that they were very poorly allowed to exercise authority and responsibility.

Majority of the respondents conduct procurement planning but the rate and frequency of disbursement of funds affect their planning. The rate of disbursement was felt to be very low especially from respondents who indicated that they were serving within the National and County Government entities. Those serving in the education institutions seemed not to be affected much by the levels of disbursements. This feeling was the same for Parastatals and semi-autonomous Government agencies that did not appear to be affected by the rate of disbursement. This could be as a result of their ability to generate revenues through other sources as Appropriations - In- Aid thus not adversely affected by the frequency of releases. The implementation of the public procurement laws would not be possible without the monitoring to ensure compliance with the same laws. From the study there is a lot to be done by the body entrusted with the responsibility to enforce compliance. Only few of the respondents reported to have been monitored for compliance. It is encouraging to note that majority of the respondents have some level of internal compliance mechanisms. Once again majority of these were respondents from the education sector. They also had the highest number of professionals manning their procurement units. A high number of respondents also felt that lack of compliance monitoring affected their implementation of the public procurement laws. The presence of monitoring would therefore improve the levels of compliance with the laws owing to the attendant sanctions against the offenders.

This study therefore reinforces the earlier studies conducted in finding the factors impeding the full implementation of public procurement laws. It advances the contingency theory which states that there is no one best way to organize a corporation, to lead a company or to make decisions and that the optimal course of action is contingent or dependent upon the internal and external situation. No single factor can ensure full implementation of the public procurement laws and it calls on all the variables identified to ensure implementation of the public procurement laws. The study also enforces the agency theory in that there has to exist a relationship between the procurement staff and the leadership of public procurement entities in the provision of a conducive environment to perform and fully implementing the public procurement laws. The leadership entrusts the staff as its agents in implementing the laws and the leadership is obligated to ensure that the agents are well facilitated to accomplish the task to the satisfaction of the principle.

Contextually, this study adds to the practice of procurement and supply chain management by expanding the knowledge of the enablers in implementation of procurement laws which ultimately leads to the profession meeting its strategic goals of contributing to the overall improvement of the entities be they public or private and also provides room for further research in the field of procurement and supply chain. 
The study makes the following recommendations

\section{The Authorities for Implementation}

Part ii, section 7(d) of the Public Procurement and Asset Disposal Act 2015 specifically mandates the National Treasury to provide technical assistance on procurement and assist in the implementation and operation of the public procurement and asset disposal system while section 7(e) of the same Act gives the National Treasury the mandate to manage and administer the scheme of service of the procurement and supply chain cadre for the national Government and Part (iii) of the Act, section 33(h) mandates the officer in charge of the county treasury to administer the scheme of service for county government procurement and supply chain management officers and capacity building. It is therefore highly recommended that they ensure the staff with the relevant training and qualifications in procurement man the procurement units. Other categories should also ensure qualified professionals are hired to lead the procurement units

The accounting officers of the public procurement entities should also ensure that the right support is given to the procurement units in terms of facilities and facilitation to perform better. The procurement departments should be given room to act as professionals in their units in exercising their responsibilities as per the procurement laws which include the act, the Regulations and the Circulars made from time to time by the Public Procurement Regulatory Authority.

The Public Procurement Regulatory Authority being the body mandated by the law to enforce compliance of the law should put more effort in ensuring that more public procuring entities are monitored continuously to ensure compliance with the laws and capacity built where shortcomings are identified. This will help in making procurement what it truly is; a catalyst to development and improvement of the living standard of the citizens.

\section{Service Users/Beneficiaries}

The public procuring entities should view procurement department as an integral component in the actualizing of their plans. The department should be incorporated into the strategic planning of the service delivery. Those entities or organizations which have incorporated procurement units at their strategic level have already realized the benefits which accrues from the expertise of the department. Every service, works or goods bought for either resale, production or service, the input of the procurement unit is crucial for profitability and timely or efficient service delivery. All the necessary support including adequate staffing with requisite numbers and skills, facilitation in terms of funding for skills development, training and equipment and creating an enabling environment in which the decisions, responsibility and authority can be exercised in matters procurement. By doing this the department would not only ensure compliance with the procurement laws but also derive the benefit accruing from full implementation of procurement laws in this country hence meeting the objectives of the public procurement laws.

It's also recommended that procurement units put in place policies to ensure that there is a sound internal public procurement laws compliance mechanisms. These could be in form of guidelines on how the entire procurement process is handled by different sections within the supply chain and also a strong inspection and acceptance committees to vet deliveries before payments are made. 


\section{Other Stakeholders}

The effective implementation of Public procurement would greatly improve the service delivery to the citizens. Being the vehicle through which governments improve the living standards of the people, it is incumbent upon all stakeholders to ensure that the public procurement laws are implemented. Adherence to public procurement processes should therefore be a prerogative of all stakeholders. Public procurement entails sourcing for goods, services and works from the private sector into use by the public sector. This therefore means that everyone including the private sector players have the task of ensuring compliance with the public procurement laws.

\section{Further Research in the Field of Study}

Procurement like any other business discipline is continuously experiencing new and emerging challenges in the wake of global trends in the supply chain. The ever changing business environment also makes it necessary to continuously search for innovative ways to ensure that procurement and especially public procurement is able to meet the stakeholders' expectations. This study used closed ended questions and it would be interesting to replicate the study using open ended questions in order to understand why majority of the respondents had such strong negative responses on certain questions and this would perhaps better or improve implementation of the public procurement laws.

Secondly this study was conducted entirely in Meru County. For the purpose of generalizing, a recommendation for a similar study conducted in a different county would help in confirming the findings or finding any deviation from the findings of this study and as such better understanding of the enablers in the implementation of public procurement laws as well add to the body of knowledge in Public procurement.

\section{References}

Alchian, A., \& Demsetz, H. (1972) Production, Information costs and Economic Organization. American Economic Review, 62 (4)777-795.

Ameyaw, C., Mensah, S., \& Osei-Tutu, E. (2011). Challenges Facing the Smooth Implementation of Act 663, 2003 of Ghana: West African Built Environment Research Conference, University of Reading, 2011.

Ameyaw, C., Mensah, S., \& Osei-Tutu, E. (2012). Public Procurement in Ghana: The Implementation challenges to the Public Procurement Laws 2003, International Journal of Construction Supply Chain Management (2) 55-65.

Ambe, I. M., \& Badenhorst-weiss, J. A. (2012). Procurement Challenges in South African Public Sector. Journal of Transport and Supply Chain Management.

Anthon, S., Bogetoft, P., \& Thorsen, B. J. (2007). Socially optimal procurement with tight budgets And rationing; Journal of Procurement Economics 91(7)1625-1642.

Barbara, G. K. (2006). What is Research Design? The context of Design? Performance studies methods course syllabus. New York University, spring.

Bastagli, F., Coady, D., \& Gupta, S., (2012). Income Inequality and Fiscal Policy No. 12/08R. IMF.

Chiboiwa, M. W., Samwel, M. O., \& Chipunza, C. (2010). An Examination of Employee Retention Strategy in Private Organizations in Zimbabwe; African Journal of Business Management. 
Darwish, S., Alzayed, S., \& Ahmed, U. (2020). How Women in Science can Boost Women's Entrepreneurship: Review and Highlights. International Journal of Innovation Creativity and Change, 14(1), 453-470.

Daly, H. (2015). 'Conflicts of Interest in Agency Theory: a theoretical overview'15 (1) Global Journal of Human-Social Science: Economics.

Dzuke, A., \& Naude, M. (2015). Procurement Challenges in the Zimbabwe Public Sector: A Preliminary Study; Journal of Transport and Supply Chain Management.

Eisenhardt K. M. (1989). 'Agency Theory: An Assessment and Review'14 (1): Academy of Management Review.

Gelderman, J. C., Ghisen, W. P., \& Brugman, J. M. (2006), Public Procurement and EU tendering directives: Explaining non-compliance; International Journal of Public Sector Management 19(7).

Gesuka, D. M., \& Namusonge, G. S. (2013). Factors Affecting Compliance of Public Procurement Regulation in Kenya: A case Study of Butere District. International Journal of Social Sciences and Entrepreneurship, 1(5), 882-896.

Gillott, R., \& Wong, R. (2016). Compliance challenges with BPS Procurement Directive: Osler

Gocke, A. (2008). Challenges facing procurement organizations

GOK. (2016), Public procurement and Asset Disposal Act 2015, Government Printer, Nairobi

GoK. (2010).The Constitution of Kenya. National Council for Law Reporting, Nairobi

Gorard Stephen. (2013). Research Design: Creating Robust Approaches for Social Sciences, Thousands Oak, CA: Sage

Gordon, M. E., \& Miller, V. D. (2012). Conversation about Job Performance: A communication perspective on the Appraisal process. New York NY 10017: Business Expert Press

GOK. (2007). Public Procurement and Disposal Act 2005. Government Printer, Nairobi.

GOK. (2007). Public Procurement and Disposal Regulation2006. Government Printer, Nairobi. Handfield. (2011). The Role of Procurement Within an Organization; A Tutorial, Supply Chain Management Resource Cooperative, Poole College of Management, North Carolina State University in Raleigh.

Harland, C., Knight, L., Caldwell, N. (2006). International Research Study of Public procurement http://cips.org/>.

Hellawell, J. M. (1991). Development of Rationale for Monitoring; Springer, Dordrecht

Howard, L. W., \& Miller, J. L. (1993). Fair Pay for Fair Play; Estimating Pay Equity in Professional Baseball with Data Envelopment and Analysis, Academy of Management Journal.

Hunja, R. R. (2003). Obstacles to Public Procurement Reforms in Developing Countries, in S. Arrowsmith \& M. Trybus (eds) Procurement: The Continuing Revolution.

Jensen M. C., Meckling, W. H. (1976). 'Theory of the firm: managerial behavior, agency cost and ownership structure'3 (4): Journal of Financial Economics305-360.

Kiama, G. P. (2014). Factors Affecting Implementation of Public Procurement Act in SACCO Societies in Kenya; International Journal of Academic Research in Business and Social Sciences 4(2) 169-194.

Kombo, D. K. \& Tromp, D. L. A. (2011). Proposal and Thesis Writing, Paulines Publications Africa, Nairobi.

LaHarpe, D., \& LeRoux, P. (2009). Public Procurement Law: A Comparable Analysis, Doctoral Study; University of South Africa, Pretoria.

Mahmood, S. A. (2010). Public Procurement and Corruption in Bangladesh; Confronting the Challenges and Opportunities; Journal of Public Administration and Policy Research 2, 103-111. 
Mauro, P., Romeu, R., Binder, A., \& Zaman, A. (2015). A Modern History of Fiscal Prudence and Profligacy. Journal of Monetary Economics. IMF Fiscal Department.

Mehran, S., \& Inman, R. A. (2004). Purchasing Management and Business Competitiveness in the Coming Decade, Production Planning \& Control 15(7), 710-718.

Monczka, R., Handfield, R., Giunipero, L., \& Patterson, J. L. (2008). Purchasing and Supply Management, Cengage Learning, New York.

Mugo, H. (2013). Determinants of Procurement Regulatory Compliance in Kenya Electricity Generating Company: International Journal of Social Science and Entrepreneurship 1(7) 267-275

Muriungi, I. (2014). Public Participation and civilian Oversight: The key to Improving integrity in Public Procurement, Transparency International: Advocacy and legal advisory Centre.

OECD. (2007). Integrity in Public Procurement: Good Practice from A to Z, OECD Publishing.

OECD. (2015). Consequences of Corruption at the Sector Level and Implication for Economic Growth and Development: OECD Publishing, Paris.

Ojo, E. A., \& Gbadebo, A. M. (2014). An Assessment of Non-compliance with Procurement Proceedings in procurement of works in Nigeria: International Journal of Economic and Business Management 2(3) 25-34.

Osei-Tutu, E., Mensah, S., \& Ameyaw, C. (2011). The Level of Non-compliance in Public Procurement Act (663) of Ghana: Journal of Public Procurement and Contract Management 1(1)54.

PPOA. (2006). Assessment of the Procurement System in Kenya, Rambøll.

PPOA. (2017). Annual Report: Financial year 2016 Press.

Ross, S. (1973). The Economic Theory of Agency: The Principal's Problem' 62 (2) American Economic Journal.

Rungtusanatham, M., Ravinovich, E., Baum, A. B., \& Walin, C. (2007). Vendor Owned Inventory Management Arrangement in Retail; An agency Theory Perspective. Journal of Business Logistics, 28(1), 11-35.

Soumare, I., \& Gouhou, G. (2009). Impact of FDI on poverty Reduction in Africa: Are there Regional Differences? African Development Forum, Addis Ababa.

TI Kenya. (2018) Public Procurement in Kenya: Cash Cow for the Corrupt or Enabler for Public Service Delivery? Issue 145.

Van Eerde, W., \& Thierry, H. (1996).Vrooms Expectancy Model and Work Related Criteria: A Meta-Analysis: Journal of Applied Psychology 81 (5)575.

Van Weele, A. J. (2014). Purchasing and Supplies Chain Management, 6th edition: Cengage Learning, Singapore.

World Bank. (2017). The World Bank Annual Report 2017:worldbank.org/annual report. 